\title{
Well-defined poly(oxazoline)-b-poly(acrylate) amphiphilic copolymers: from synthesis by polymer-polymer coupling to self-organization in water
}

Brieuc Guillerm, Sophie Monge, Vincent Lapinte, Jean-Jacques Robin

Institut Charles Gerhardt Montpellier UMR5253 CNRS-UM2-ENSCM-UM1 - Equipe Ingénierie et Architectures Macromoléculaires, Université Montpellier II cc1702, Place Eugène Bataillon 34095 Montpellier Cedex 5, France

Correspondence to: V. Lapinte (E-mail: vincent.lapinte@univ-montp2.fr)

Additional Supporting Information may be found in the online version of this article.

\begin{abstract}
In this contribution, we report on the self assembly in water of original amphiphilic poly(2-methyl-2oxazoline)- $b$-poly(tert-butyl acrylate) copolymers, synthesized by copper catalyzed azide-alkyne cycloaddition (CUAAC) reaction. For such purpose, polyoxazoline (poly(2-methyl-2-oxazoline)) and polyacrylate (poly(tert-butyl acrylate)) are first prepared by cationic ring-opening polymerization (CROP) and atom transfer radical polymerization (ATRP), respectively. Well-defined polymeric building blocks, $\omega-N_{3}-P(t-B A)$ and $\alpha$-alkyne-P(MOx), bearing reactive chain end groups, are accurately characterized by MALDI-Tof spectroscopy. Then, $\mathrm{P}(\mathrm{MOx})_{\mathrm{n}}-\mathrm{b}-\mathrm{P}(\mathrm{t}-\mathrm{BA})_{\mathrm{m}}$ are achieved by polymer-polymer coupling and are fully characterized by DOSY NMR and size exclusion chromatography, demonstrating the obtaining of pure amphiphilic copolymers. Consequently, the latter lead to the formation in water of well-defined monodisperse spherical micelles $\left(R_{H}=40-60 \mathrm{~nm}\right)$ which are studied by fluorescence spectroscopy, SLS, AFM and TEM.
\end{abstract}

KEYWORDS: atom transfer radical polymerization (ATRP); ring-opening polymerization; self-assembly; polyoxazolines, synthesis 


\section{INTRODUCTION}

The increasing interest of amphiphilic copolymers mainly arose from their self-organization in water leading to the formation of micelles ${ }^{1-2}$ where hydrophobic core is surrounded by a hydrophilic corona. This property was employed for the encapsulation of chemicals using polymeric drug carriers, ${ }^{3}$ as well as for the synthesis of membranes, ${ }^{4}$ for instance. Many routes led the synthesis of amphiphilic copolymers using sequential polymerization of CROP and CRP ${ }^{5}$ and especially CROP and RITP. ${ }^{6}$ Dual initiators ${ }^{7}$ and dual terminating agents ${ }^{8}$ have also employed to the synthesis of such architectures. Among all the possible synthesis pathways, the polymer-polymer coupling appeared to be an attractive approach providing notably straightforward access to block copolymers with the control over each block in terms of molecular weight, and functionality.

Over the last few years, polymer-polymer coupling using "click" chemistry showed enormous potential for material science. ${ }^{9-11}$ One of the great advantages of this concept was for example the possibility to combine homopolymers preliminary prepared by various living polymerization techniques, such as ringopening polymerization (ROP), ring-opening metathesis polymerization (ROMP), cationic polymerization, nitroxide-mediated radical polymerization (NMP), atom transfer radical polymerization (ATRP), and reversible addition fragmentation chain transfer polymerization (RAFT). Thus, various orthogonal and efficient coupling reactions such as thiol-ene or thiol-ene based Michael addition reactions, ${ }^{12-13}$ and Diels-Alder reactions ${ }^{14}$ were successfully carried out. Additionally, Huisgen's cycloaddition catalyzed by copper (CUAAC) was investigated to produce block copolymers but only few examples of CuAAC polymer-polymer coupling dealt with the synthesis of amphiphilic copolymers. Indeed, in general, another strategy was used for such purpose involving the Huisgen's cycloaddition with two hydrophobic segments followed by a post-polymerization reaction onto one block to afford amphiphilic copolymers. ${ }^{15-16}$ Only limited examples reported the direct CuAAC polymer-polymer coupling between hydrophobic and hydrophilic homopolymers as this reaction is not privileged due to the antagonist properties of both blocks, and high reactivity of polymer end chains was required to efficiently connect the building blocks. Examples described in the literature reported the use of poly(ethylene oxide) (PEO) as hydrophilic block associated with polystyrene, poly(methyl methacrylate), ${ }^{17}$ or poly(3hydroxyalcanoate)s. ${ }^{18}$ In another work, poly(N-isopropylacrylamide) was associated to poly(6-[4-(4methoxyphenylazo)phenoxy]hexyl methacrylate). ${ }^{19}$ The coupling between two hydrophilic homopolymers was described using PEO and poly(2-methyl-2-oxazoline) ${ }^{20}$ or 2-hydroxyethyl acrylate and 2-oxazoline. ${ }^{21}$ Finally, an example dealing with poly(2-methyl-2-oxazoline) in amphiphilic copolymer reported in the literature dealt with poly(3-hydroxybutyrate-co-3-hydroxyvalerate)- $b$-poly(2-methyl-2oxazoline) diblock copolymers ${ }^{22}$ but no study of the self-organization of such amphiphilic structures was carried out. The only work detailing the synthesis and the self-organization of amphiphilic copolymer based on polyoxazoline and obtained by polymer-polymer coupling is in the recent article of Theogarajan. ${ }^{23}$ However the copolymer is triblock copolymer PMOx-b-PDMS-b-PMOx.

In this contribution, we reported on the self-assembly of original amphiphilic diblock copolymers based on poly(2-methyl-2-oxazoline) $(\mathrm{P}(\mathrm{MOx}))$ and poly(tert-butyl acrylate) $(\mathrm{P}(\mathrm{t}-\mathrm{BA}))$. $\mathrm{P}(\mathrm{MOx})$ can be regarded as alternative to PEO due to its hydrophilicity, ${ }^{24}$ biocompatibility, and low toxicity which made it an 
appropriate candidate for biomedical applications. ${ }^{25-30}$ On the other hand, hydrophobic $\mathrm{P}(\mathrm{t}-\mathrm{BA})$ can be easily functionalized by trans-esterification ${ }^{31}$ or converted into biocompatible hydrophilic poly(acrylic acid). ${ }^{32}$ The $\mathrm{P}(\mathrm{MOx})$ and $\mathrm{P}(\mathrm{t}-\mathrm{BA})$ building blocks were synthesized by CROP and ATRP processes, respectively. The alkyne and azide terminal functionalizations were carefully characterized by MALDI-Tof spectroscopy and polymer-polymer coupling was then achieved using Huisgen's cycloaddition reaction. Self-assembly of resulting amphiphilic diblock copolymers in water was studied by AFM, TEM, DLS and fluorescence spectroscopy.

\section{EXPERIMENTAL}

\section{Materials}

Propargyl tosylate, diethylether, methanol, chloroform, potassium hydroxide, calcium hydride $\left(\mathrm{CaH}_{2}\right)$, sodium, ethyl 2-bromoisobutyrate, tetrabutylammonium fluoride (TBAF) solution (1.0 $\mathrm{M}$ in THF), potassium fluoride, azidotrimethylsilane and $\mathrm{N}, \mathrm{N}, \mathrm{N}^{\prime}, \mathrm{N}^{\prime \prime}, \mathrm{N}^{\prime \prime}$-pentamethyldiethylenetriamine (PMDETA) were purchased from Aldrich and were used as received. Acetonitrile was dried and distilled according to standard procedures. ${ }^{33}$ Tetrahydrofuran (THF) and N,N-dimethylformamide (DMF) were distilled under vacuum over sodium. 2-Methyl-2-oxazoline ( $\mathrm{MOx}$ ) was dried, distilled from $\mathrm{CaH}_{2}$ and stored under a dry nitrogen atmosphere. Tert-butyl acrylate (t-BA) (Aldrich, 98\%) was passed through a column of alumina to remove inhibitor. Copper (I) bromide (Aldrich, 98\%) was purified according to standard procedures. ${ }^{34}$ Deuterated solvents $\left(\mathrm{CDCl}_{3}, \mathrm{CD}_{3} \mathrm{CN}\right.$ and DMF- $\left.d_{7}\right)$ were purchased from SDS and were used without further purification.

\section{Analytical techniques}

${ }^{1} \mathrm{H}$ NMR spectra were recorded using a Bruker AMX 300 operating at $300 \mathrm{MHz}$. Chemical shifts were referenced to the peak of residual non-deuterated solvent. DOSY experiments were performed on a Bruker Advance 3 at $20{ }^{\circ} \mathrm{C}$ in $2.5 \mathrm{~mm}$ microtubes operating at $600 \mathrm{MHz}$ with DMF- $d_{7}$ as solvent. The software used was Topspin 2.1 using the exponential method with a logarithmic scale. Size exclusion chromatography (SEC) of $\mathrm{P}(\mathrm{MOx})$ was performed on a PL-GPC 50 Plus equipped with a RI refractive index detector in a mixture of $\mathrm{H}_{2} \mathrm{O} / \mathrm{CH}_{3} \mathrm{OH} 7 / 3, \mathrm{v} / \mathrm{v}\left(+0.1 \mathrm{M} \mathrm{LiNO}_{3}\right)$. Three PL aquagel-OH columns $(25,7.5$ and $4.6 \mathrm{~mm}$ ID) were used at $40{ }^{\circ} \mathrm{C}$ with a $0.8 \mathrm{~mL} \cdot \mathrm{min}^{-1}$ flow rate, calibrated using PEO standards. Size exclusion chromatography (SEC) of $\mathrm{P}(\mathrm{t}-\mathrm{BA})$ was performed on a $\mathrm{PL}$ Mixed D equipped with a RI refractive index detector in THF. Three PLGel 500,103,104 columns were used at $30^{\circ} \mathrm{C}$ with a $1 \mathrm{~mL}$. $\mathrm{min}^{-1}$ flow rate, calibrated using PMMA standards. Size exclusion chromatography $(\mathrm{SEC})$ of $\mathrm{P}(\mathrm{MOx})_{\mathrm{n}}-b-\mathrm{P}(\mathrm{t}-\mathrm{BA})_{\mathrm{m}}$ samples was performed on a Waters apparatus equipped with an RI refractive index detector in DMF. Three TSK columns (G2000, G3000, G4000 HHR) were used at $70{ }^{\circ} \mathrm{C}$ with a $0.8 \mathrm{~mL}$. $\mathrm{min}^{-1}$ flow rate, calibrated using PMMA standards. Mass spectrometry analyses were conducted with a Bruker Ultra-Flex MALDI-Tof mass spectrometer, equipped with a nitrogen laser (LSI, $337 \mathrm{~nm}, 10 \mathrm{~ns}$ pulse length) and one detector. Mixture of peptides was used for external calibration. The ions were accelerated by a potential of $25 \mathrm{kV}$ and reflected with a $26.3 \mathrm{kV}$ potential. $\mathrm{P}(\mathrm{MOx})$ samples were recorded in the reflection mode using $\alpha$ cyano-4-hydroxycinamic acid (HCCA) matrix with $\mathrm{CF}_{3} \mathrm{COOK}$ salt. $\mathrm{P}(\mathrm{t}-\mathrm{BA})$ samples were recorded in the reflection mode using 2,3-dihydrobenzoic acid and Nal. For each spectrum 300 transients were 
accumulated. $\mathrm{P}(\mathrm{MOx})$ and $\mathrm{P}(\mathrm{t}-\mathrm{BA})$ were dissolved in acetonitrile and THF, respectively, at a concentration of $10 \mathrm{mg} \cdot \mathrm{mL}^{-1}$. Static Light Scattering (SLS) and Dynamic Light Scattering (DLS) measurements were performed on a Malvern Zetasizer Nano ZS equipped with a $4 \mathrm{~mW}$ He-Ne laser $(\lambda=$ $632.8 \mathrm{~nm}$ ). Measurements were carried at a scattering angle of $173^{\circ}$. Samples were introduced into cells (pathway: $10 \mathrm{~mm}$ ) after filtration through $0.45 \mu \mathrm{m}$ PTFE microfilters. The correlation function was analyzed via the general purpose method (NNLS) to obtain the distribution of diffusion coefficients (D) of the solutes. For the dynamic properties, the apparent equivalent hydrodynamic radius $\left(R_{H}\right)$ and the dispersity were determined from the cumulant algorithm using the Stokes-Einstein equation:

$$
\mathrm{R}_{\mathrm{H}}=\frac{\mathrm{k}_{\mathrm{B}} \mathrm{T}}{6 \pi \eta \Gamma} \mathrm{q}^{2}=\frac{\mathrm{k}_{\mathrm{B}} \mathrm{T}}{6 \pi \eta \mathrm{D}_{0}}
$$

where $k_{B}$ : Boltzmann constant, $T$ : temperature of the sample, $\Gamma$ : relaxation frequency, q: wave vector, $\eta$ : viscosity of the medium, and $\mathrm{D}_{0}$ : translational diffusion coefficient. Mean radius values were obtained from three runs. Standard deviations were evaluated from hydrodynamic radius distribution. The polymer concentration was $50 \mathrm{mg} \cdot \mathrm{L}^{-1}$. SLS experiments allowed the determination of the Critical Micellar Concentration (CMC) which was taken as the intersection of lines plotted on the graph corresponding to the intensity as a function of the copolymer concentration. Polymer concentrations varied from $1 \times 10^{-3}$ to $0.2 \mathrm{mg} \cdot \mathrm{mL}^{-1}$. Fluorescence measurements were achieved using a LS45 spectrometer (Shimatzu). Aggregate formation was examined over a wide range of polymer concentrations $\left(1 \times 10^{-3}-0.2 \mathrm{mg} \cdot \mathrm{mL}^{-1}\right)$ using pyrene as a fluorescent probe. Diblock copolymers were prepared in Milli-Q water, filtered using $0.45 \mu \mathrm{m}$ PTFE microfilters, and diluted as needed. To prepare the samples for fluorescence experiment, $0.25 \mathrm{~mL}$ of a pyrene solution $\left(1.9 \times 10^{-3} \mathrm{M}\right.$ in methanol) was added to $24.75 \mathrm{~mL}$ of Milli-Q water. $75 \mu \mathrm{L}$ of pyrene solution was then added to the polymer solution $(1.5 \mathrm{~mL})$ in the vial, bringing the final pyrene concentration to $9 \times 10^{-7} \mathrm{M}$. All spectra were recorded from air-equilibrated solutions. The samples were excited at $340 \mathrm{~nm}$ and emission was recorded from 330 to $450 \mathrm{~nm}$. The average fluorescence values at 383 and $373 \mathrm{~nm}$ were used for subsequent calculations. The CMC, determined by plotting the 373/384 ratio against the polymer concentration ( $\log \mathrm{mg} \cdot \mathrm{mL}^{-1}$ ), was taken as the intersection of regression lines calculated from the linear portions of the graph. Atomic force microscope (AFM) experiments were performed at room temperature using a Nanoscope 5 Veeco. Copolymers dissolved in Milli-Q water were deposited on silicon wafers treated with $\mathrm{RCA}\left(1 / 7 \mathrm{H}_{2} \mathrm{O}_{2}, 1 / 7 \mathrm{NH}_{3}, 5 / 7 \mathrm{H}_{2} \mathrm{O}\right)$ at $100{ }^{\circ} \mathrm{C}$. Samples were analyzed after complete evaporation of the solvent at room temperature. Images were acquired in air in tapping mode with a silicon tip (tip radium: $7 \mathrm{~nm}$, height: 10-15 $\mu \mathrm{m}$ ), a spring constant of $42 \mathrm{~N} \cdot \mathrm{m}^{-1}$, a resonance frequency equal to $330 \mathrm{kHz}$, and a radius of curvature in the $10-15 \mathrm{~nm}$ range. Processing and analysis of AFM images were performed with WSxM 5.0 Develop 3.2 software. ${ }^{35}$ Transmission electronic microscopy (TEM) experiments were performed at room temperature using a JEOL 1200 EXII. The samples were prepared by placing a drop of an aqueous solution $(0.025 \% \mathrm{w} / \mathrm{v})$ of the diblock copolymer onto a carbon-coated copper grid. Samples were analyzed after complete evaporation of the solvent. Differential scanning calorimetry (DSC) was performed using a DSC1 apparatus (Mettler Toledo). Samples were heated from -100 to $100{ }^{\circ} \mathrm{C}$ at a $10{ }^{\circ} \mathrm{C} \cdot \mathrm{min}^{-1}$ heating rate. Glass transition temperatures $\left(\mathrm{T}_{\mathrm{g}}\right)$ were measured at the third heating. 
Typical procedure of MOx polymerization using propargyl tosylate initiator: $\alpha$-alkyne-P(MOx)

The polymerization was carried out using procedures described in the literature. ${ }^{36}$

${ }^{1} \mathrm{H}$ NMR $\left(300 \mathrm{MHz}, \mathrm{CDCl}_{3}\right) \delta(\mathrm{ppm}): 4.2\left(\mathrm{~m}, \mathrm{~N}-\mathrm{CH}_{2}-\mathrm{C} \equiv \mathrm{CH}\right)$, 3.5-3.1 (m, $\left.\mathrm{CH}_{2} \mathrm{P}(\mathrm{MOx})\right), 2.4\left(\mathrm{~s}, \mathrm{CH}_{2}-\mathrm{C} \equiv \mathrm{CH}\right)$, 2.3$2.0\left(\mathrm{~m}, \mathrm{CH}_{3} \mathrm{P}(\mathrm{MOx})\right)$.

Typical procedure for the synthesis of $\omega-\mathrm{N}_{3}-\mathrm{P}(\mathrm{t}-\mathrm{BA})$

The polymerization was carried out using procedures described in the literature ${ }^{37-38}$ with ethyl-2bromoisobutyrate as initiator to afford $\omega-\mathrm{Br}-\mathrm{P}(\mathrm{t}-\mathrm{BA})$.

${ }^{1} \mathrm{H}$ NMR (300 MHz, $\left.\mathrm{CDCl}_{3}\right) \delta(\mathrm{ppm}): 4.1$ (q, O- $\left.\underline{\mathrm{CH}}_{2}-\mathrm{CH}_{3}\right)$, 2.3-2.0 (m, CH P(t-BA)), 1.8-1.7 (m, $\mathrm{CH}_{2} \mathrm{P}(\mathrm{t}-\mathrm{BA})$ ), 1.5-1.3 (m, $\mathrm{CH}_{3} \mathrm{P}(\mathrm{t}-\mathrm{BA})$ and gem $\left.\mathrm{CH}_{3}\right), 1.1$ (s, O- $\left.-\mathrm{CH}_{2}-\mathrm{CH}_{3}\right)$.

$\omega-B r-P(t-B A)\left(M_{n, t h}=5200 \mathrm{~g} \cdot \mathrm{mol}^{-1}, 1.06 \mathrm{~g}, 0.192 \mathrm{mmol}\right)$ was dissolved in $15 \mathrm{~mL}$ of THF under nitrogen atmosphere. A solution of TBAF $1 \mathrm{M}(0.58 \mathrm{~mL}, 0.58 \mathrm{mmol})$, potassium fluoride $(33.6 \mathrm{mg}, 0.58 \mathrm{mmol})$ and trimethylsilylazide $(66.2 \mathrm{mg}, 0.58 \mathrm{mmol})$ were added. The solution was vigorously stirred at room temperature during one day. The polymer was purified by filtration through a basic alumina column to afford $85 \%$ yield in $\omega-\mathrm{N}_{3}-\mathrm{P}(\mathrm{t}-\mathrm{BA})$.

${ }^{1} \mathrm{H}$ NMR $(300 \mathrm{MHz}, \mathrm{CDCl})_{3} \delta(\mathrm{ppm}): 4.1\left(\mathrm{q}, \mathrm{O}-\mathrm{CH}_{2}-\mathrm{CH}_{3}\right), 3.8\left(\mathrm{~m}, \mathrm{CH}-\mathrm{N}_{3}\right)$, 2.4-2.0 (m, $\left.\mathrm{CH} \mathrm{P}(\mathrm{t}-\mathrm{BA})\right)$, 1.8-1.7 (m, $\left.\mathrm{CH}_{2} \mathrm{P}(\mathrm{t}-\mathrm{BA})\right)$, 1.7-1.4 (m, $\mathrm{CH}_{3} \mathrm{P}(\mathrm{t}-\mathrm{BA})$ and $\left.\mathrm{gem} \mathrm{CH}_{3}\right), 1.1\left(\mathrm{~s}, \mathrm{O}-\mathrm{CH}_{2}-\mathrm{CH}_{3}\right)$.

Typical procedure for the synthesis of $P(M O x)_{n}-b-P(t-B A)_{m}$ amphiphilic diblock copolymers using polymer-polymer coupling by CuAAC

$\omega-\mathrm{N}_{3}-\mathrm{P}(\mathrm{t}-\mathrm{BA})(1.50 \mathrm{~g}, 0.0385 \mathrm{mmol}), \alpha$-alkyne-P(MOx) $(0.85 \mathrm{~g}, 0.385 \mathrm{mmol})$, and $\mathrm{Cu}(\mathrm{I}) \mathrm{Br}(0.16 \mathrm{~g}, 1.15$ mmol) were dissolved in $5 \mathrm{~mL}$ of DMF. Deoxygenated PMDETA (232 mg, $1.34 \mathrm{mmol}$ ) was then added. The Schlenk tube was immersed in a thermostated oil bath at $50{ }^{\circ} \mathrm{C}$ during one week under nitrogen. The product was purified by two successive precipitation/extraction in hexane/water $(50 / 50, v / v)$ as previously described by Charreyre. ${ }^{39}$

${ }^{1} \mathrm{H}$ NMR (300 MHz, $\mathrm{CDCl}_{3}$ ) $\delta(\mathrm{ppm}): 8.0$ (s, $\mathrm{CH}$ triazole), 4.1 (q, O- $\mathrm{CH}_{2}-\mathrm{CH}_{3}$ ), 4.0 (t, N-CH P(t-BA) directly linked to the triazole), 3.7 ( $\mathrm{m}, \mathrm{CH}_{2}$ of the last $\mathrm{P}(\mathrm{MOx})$ unit), 3.65-3.1 (m, $\left.\mathrm{CH}_{2} \mathrm{P}(\mathrm{MOx})\right), 2.3-2.0\left(\mathrm{~m}, \mathrm{CH}_{3}\right.$ $\mathrm{P}(\mathrm{MOx})$ and $\mathrm{CH} \mathrm{P}(\mathrm{t}-\mathrm{BA}))$, 1.8-1.7 (m, $\left.\mathrm{CH}_{2} \mathrm{P}(\mathrm{t}-\mathrm{BA})\right)$, 1.5-1.3 (m, $\left.3 \mathrm{CH}_{3} \mathrm{P}(\mathrm{t}-\mathrm{BA})\right)$.

\section{Typical procedure for the preparation of aggregates}

$\mathrm{P}(\mathrm{MOx})_{\mathrm{n}}-b-\mathrm{P}(\mathrm{t}-\mathrm{BA})_{\mathrm{m}}(40 \mathrm{mg})$ was dissolved in DMF $(65 \mathrm{~mL})$. Water $(65 \mathrm{~mL})$ was added dropwise with a rate of $10 \mathrm{~mL} \cdot \mathrm{h}^{-1}$ to achieve a concentration equal to $0.3 \mathrm{mg} \cdot \mathrm{mL}^{-1}$. The resulting solution was dialyzed (membranes cut-off: 3000 g.mol ${ }^{-1}$ ) during three days using MilliQ water which was changed every 12 hours. Water solution was finally filtered through $0.45 \mu \mathrm{m}$ PTFE microfilters.

\section{RESULTS AND DISCUSSION}

\section{Synthesis of $\alpha$-alkyne-P(MOx) and $\omega-\mathrm{P}(\mathrm{t}-\mathrm{BA})$ functionalized homopolymers}

Functionalized $\alpha$-alkyne-poly(2-methyl-2-oxazoline) and $\omega$-azido-poly(t-butyl acrylate) homopolymers were first prepared by cationic ring-opening polymerization (CROP) and atom transfer radical 
polymerization (ATRP), respectively, in order to lead to amphiphilic $\mathrm{P}(\mathrm{MOx})_{\mathrm{n}}-b-\mathrm{P}(\mathrm{t}-\mathrm{BA})_{\mathrm{m}}$ block copolymers by polymer-polymer coupling in a second step. $\alpha$-Alkyne-P(MOx) was synthesized with very good yields (96\%) in acetonitrile at $80^{\circ} \mathrm{C}$ using propargyl tosylate as initiator. Polymerization was ended with a saturated solution of potassium hydroxyde in methanol (Scheme 1). The conversion was limited to $50 \%$ to avoid any transfer and terminating reactions (supporting information, Figures S1 and S2). ${ }^{36}$ Two $\mathrm{P}(\mathrm{MOx})$ with different molecular weights were prepared. After purification by precipitation in diethyl ether, size exclusion chromatography in water/methanol mixture permitted to determine the experimental molar mass values at 1000 and $2200 \mathrm{~g} \cdot \mathrm{mol}^{-1}$, corresponding to degrees of polymerization equal to 11 and 25, respectively, whereas the dispersity $(\Theta)$ was the same (1.2) in both cases (supporting information, Table S1).

On the other hand, $\omega-\mathrm{Br}-\mathrm{P}(\mathrm{t}-\mathrm{BA})$ were obtained by ATRP in the presence of ethyl 2-bromoisobutyrate, $\mathrm{Cu}(\mathrm{I}) \mathrm{Br}$, and PMDETA, as previously reported by Monge et al. ${ }^{37-38}$ Polymerizations were conducted in bulk at 40 or $50{ }^{\circ} \mathrm{C}$ and stopped after $70 \%$ conversion avoiding termination and transfer reactions (supporting information, Figure S3). A good agreement between experimental and theoretical molecular weights was obtained and dispersities were quite narrow (supporting information, Table S2). Three molecular weights of the $\omega-\mathrm{Br}-\mathrm{P}(\mathrm{t}-\mathrm{BA})$ building blocks were prepared: 2500,3900 and $14500 \mathrm{~g} \cdot \mathrm{mol}^{-1}$ with a dispersity inferior to 1.3. Then, in a post-polymerization reaction, $\omega-\mathrm{Br}-\mathrm{P}(\mathrm{t}-\mathrm{BA})$ was converted into $\omega$ $\mathrm{N}_{3}-\mathrm{P}(\mathrm{t}-\mathrm{BA})$ using trimethylsilyl azide, tetrabutylammonium fluoride and potassium fluoride as phase transfer reagent in THF at room temperature.

Both hydrophilic and hydrophobic building blocks were characterized by ${ }^{1} \mathrm{H}$ NMR spectroscopy in deuterated chloroform attributing notably the alkyne proton of $\alpha-\mathrm{N}_{3}-\mathrm{P}(\mathrm{MOx})$ at $\delta=2.4 \mathrm{ppm}$ (supporting information, Figure S2) as well as the $-\mathrm{CH}-\mathrm{Br}$ of $\omega-\mathrm{Br}-\mathrm{P}(\mathrm{t}-\mathrm{BA})$ at $\delta=4.15 \mathrm{ppm}$, overlapping with the methylene group brought by the ethyl-2-bromoisobutyrate initiator (supporting information, Figure S4). The post-polymerization modification of $\omega-\mathrm{Br}-\mathrm{P}(\mathrm{t}-\mathrm{BA})$ into $\omega-\mathrm{N}_{3}-\mathrm{P}(\mathrm{t}-\mathrm{BA})$ was characterized by the appearance of the signal corresponding to the proton bore by the carbon in $\alpha$ of the azido function at $\delta$ $=3.7 \mathrm{ppm}$. 


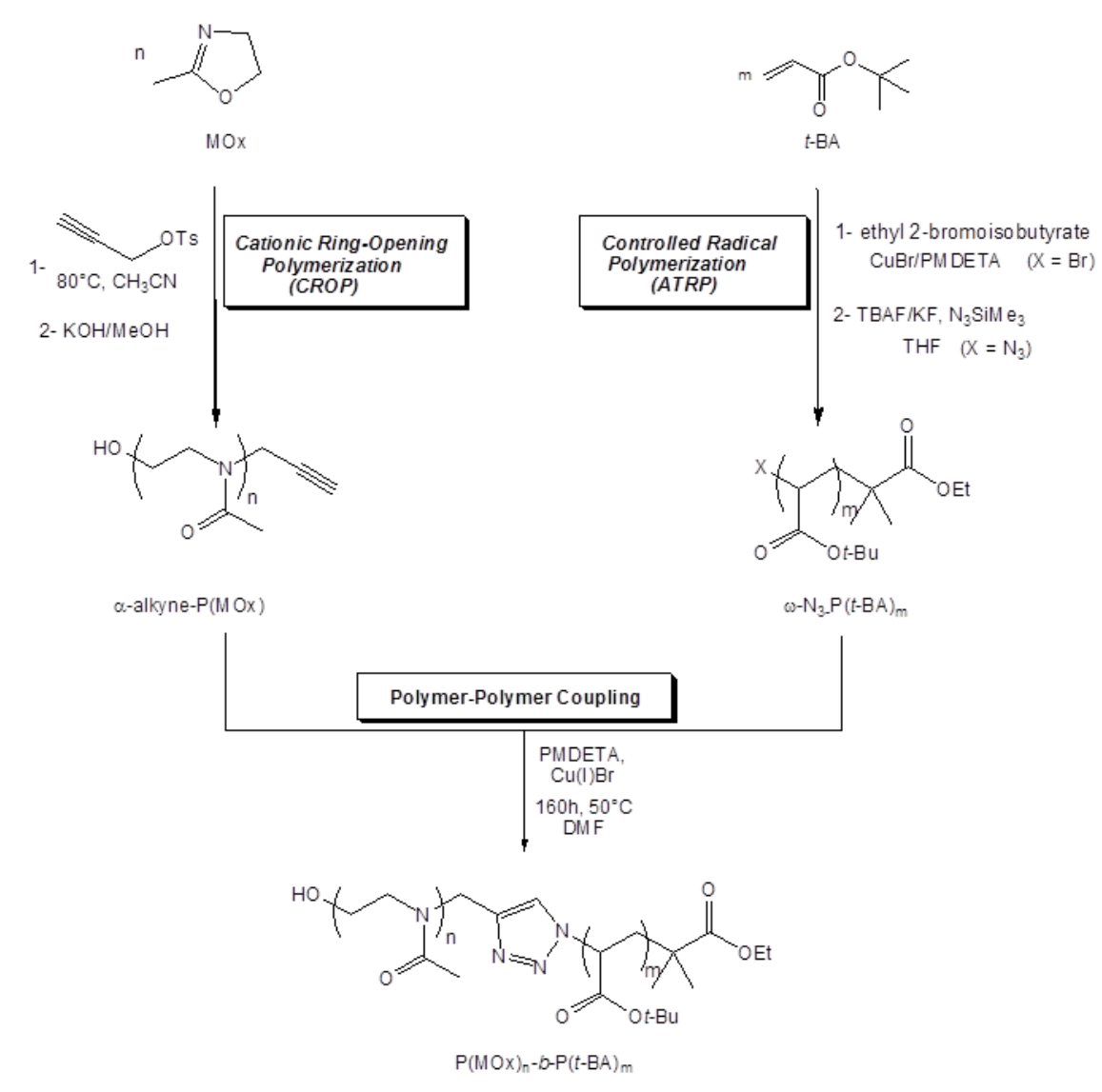

Scheme 1. Reactional pathway for the synthesis of functionalized $P(M O x)$ and $P(t-B A)$ homopolymers, and resulting amphiphilic copolymers by CUAAC polymer-polymer coupling.

The matrix-assisted laser desorption ionization time-of-flight (MALDI Tof) mass spectrometry was used to confirm the nature of $\alpha$-alkyne-P(MOx) and $\omega-\mathrm{N}_{3}-\mathrm{P}(\mathrm{t}-\mathrm{BA})$ end-groups. This study permitted the attribution of all distributions encountered in each spectrum. The abbreviation Polymer ${ }_{\text {end group was }}^{\text {head group }}$ given to all populations taking into account the head and end groups of $\mathrm{P}(\mathrm{MOx})$ and $\mathrm{P}(\mathrm{t}-\mathrm{BA})$. In both cases, the interval between two consecutive peaks of the same family corresponded to the molecular weight of the $\mathrm{N}$-acetylethylenimine $(85.05 \mathrm{Da})$ or the tert-butyl acrylate (128.05 Da) units. In the $\alpha$ alkyne-P(MOx) spectrum, a multimodal distribution displayed six populations and the main series was centered at $2306.40 \mathrm{Da}\left(\mathrm{n}=26, \mathrm{MK}^{+}\right.$type) corresponding to the targeted structure with a potassium cation (structure 1: $\mathrm{P}(\mathrm{MOx}){ }_{\mathrm{OH}}^{\mathrm{C}=\mathrm{C}}+\mathrm{K}^{+}$) (Figure 1 and Table 1). 


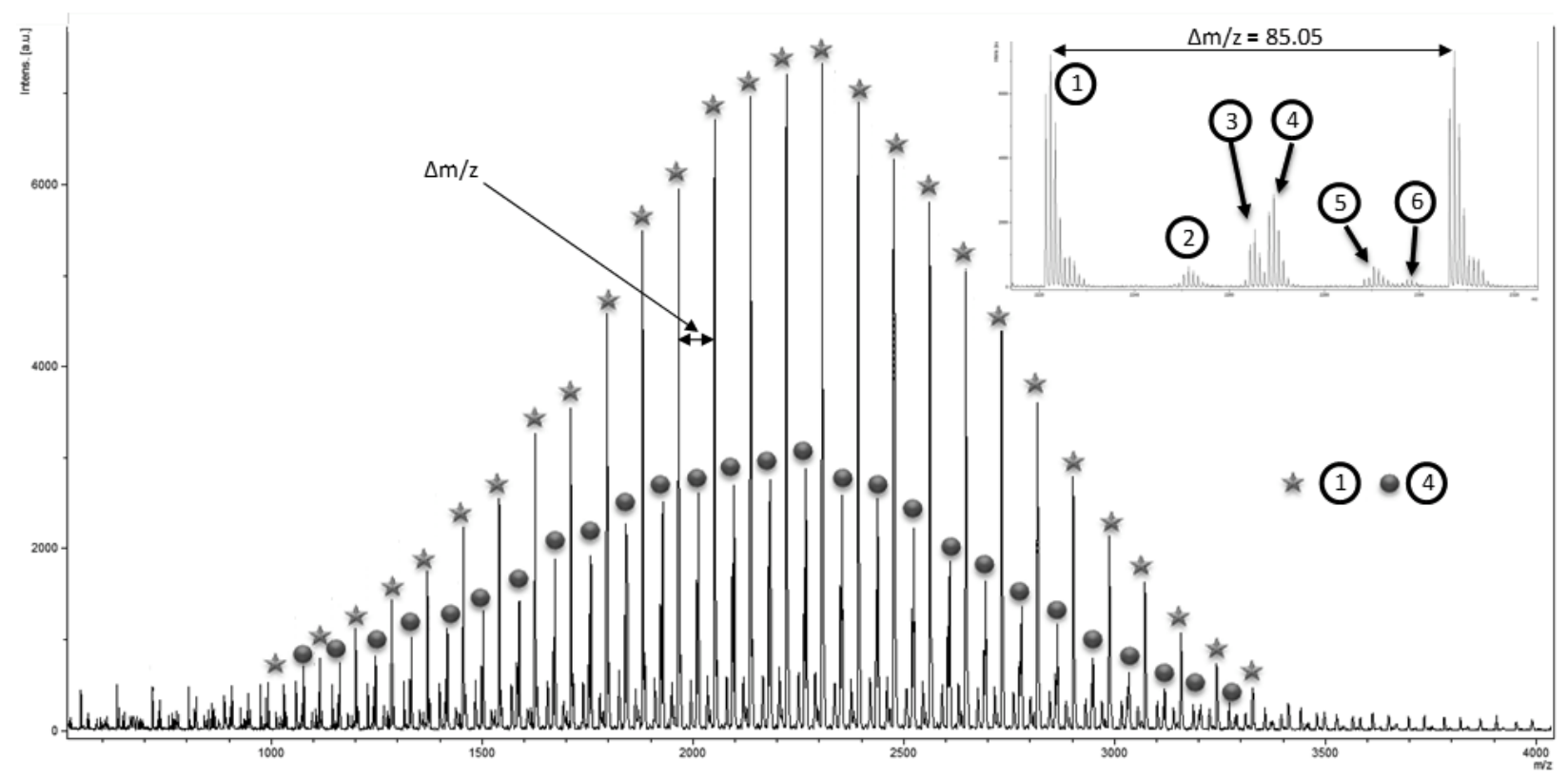

Figure 1. MALDI-Tof spectrum of the $\alpha$-alkyne- poly(2-methyl-2-oxazoline) $\left(\mathrm{M}_{\mathrm{n}, \mathrm{th}}=2600 \mathrm{~g} \cdot \mathrm{mol}^{-1}\right)(\mathrm{HCCA}$ matrix with $\mathrm{CF}_{3} \mathrm{COOK}$ salt).

More accurately, the two main populations $\left(\mathrm{P}(\mathrm{MOx}){ }_{\mathrm{OH}}^{\mathrm{C}=\mathrm{C}}+\mathrm{K}^{+}\right.$and structure $4: \mathrm{P}(\mathrm{MOx}) \underset{\mathrm{OH}}{\mathrm{C}=\mathrm{C}}+\mathrm{H}^{+}$) were attributed to the expected product with a propargylic end group, coming from the initiator and a hydroxyl group due to the terminating agent, and only differed from the associated cation (Scheme 2). Three other less abundant series exhibited alkyne head group with various end groups (structure 2: $\mathrm{P}(\mathrm{MOx})_{\mathrm{n}-1}^{\mathrm{C} \equiv \mathrm{C}=\mathrm{Oxa}}$, structure 3: $\mathrm{P}(\mathrm{MOx})_{\mathrm{n}-1_{\mathrm{NH}}^{\mathrm{C}}+\mathrm{C}}+\mathrm{K}^{+}$and structure 5: $\mathrm{P}(\mathrm{MOx})_{\mathrm{n}-1}^{\mathrm{C}=\mathrm{C}=\mathrm{C}}+\mathrm{K}^{+}$). Structure 2 was terminated by an oxazolinium end group which revealed the persistence of few propagating chains whereas structure 3 exhibited a $-\mathrm{NHCH}_{2} \mathrm{CH}_{2} \mathrm{OH}$ end group as previously described by Schubert et al. $^{40}$ in the case of the polymerization of the 2-ethyl-2-oxazoline initiated by propargyl tosylate. The $\mathrm{P}(\mathrm{MOx})$ end chain of the structure 5 was attributed to an unsatured oxazoline cycle resulting from transfer reaction between propagating chain and monomer. ${ }^{41}$ Finally, a very small distribution (structure 6: $\mathrm{P}(\mathrm{MOx})_{\mathrm{n}-1}^{\mathrm{H}} \underset{\mathrm{Oxa}}{\mathrm{H}}$ ) corresponded to a $\mathrm{P}(\mathrm{MOx})$ with a proton as head group and an oxazolinium specie as end group. This structure resulted from the partial initiation with paratoluenesulfonic acid $\left(\mathrm{H}^{+}\right)$, which was a by-product coming from the hydrolysis of the tosylate initiator. ${ }^{42} \mathrm{~A}$ second explanation of the $\mathrm{H}$-head group of polyoxazoline appearance should correspond to the transfer reaction between propagating chain and monomer which yields to the structure 5 and an oxazoline specie bearing $\mathrm{H}-\mathrm{N}$ bond. The modified oxazoline results from the nucleophilic attack of a MOx unit on the proton coming from the elimination on the propagating specie. Thus, the attack of another MOx unit on the modified oxazoline generates propagating polyoxazoline chain bearing proton head group. To conclude, the MALDI-Tof experiment on $\alpha$-alkyne-P(MOx) demonstrated that the latter was terminated by an alkyne function in all cases except for not abundant structure 6 . 
Table 1. Analytical data derived from MALDI-Tof spectroscopy for the characterization of $\alpha$-alkyne poly(2-methyl-2-oxazoline) $\left(\mathrm{M}_{\mathrm{n}, \mathrm{th}}=2600 \mathrm{~g} \cdot \mathrm{mol}^{-1}\right)$.

\begin{tabular}{|c|c|c|c|c|c|c|}
\hline Assignment & $\mathrm{RM}_{\text {formula }}$ & $\mathbf{R M}_{\text {calc }}$ & $\mathbf{R M}_{\exp }$ & $M_{p, c a l}$ & $M_{p, \exp }$ & Calculation \\
\hline $\mathrm{P}(\mathrm{MOx})_{\mathrm{n}} \underset{\mathrm{OH}}{\mathrm{C}=\mathrm{C}}+\mathrm{K}^{+}$(1) & $\mathrm{C}_{3} \mathrm{OH}_{4} \mathrm{~K}$ & 95.1 & 95.05 & 2221.35 & 2221.31 & $\mathrm{n} * 85.05+\mathrm{RM}$ \\
\hline $\mathrm{P}(\mathrm{MOx})_{\mathrm{n}-1} \stackrel{\mathrm{C} \equiv \mathrm{Oxa}}{\mathrm{C}}(2)$ & $\mathrm{C}_{7} \mathrm{NOH}_{10}$ & 124 & 124.15 & 2250.25 & 2250.44 & $(n-1) * 85.05+R M$ \\
\hline $\mathrm{P}(\mathrm{MOx})_{\mathrm{n}-1_{\mathrm{NH}}}^{\mathrm{C}=\mathrm{C}}+\mathrm{K}^{+}(3)$ & $\mathrm{C}_{5} \mathrm{ONH}_{9} \mathrm{~K}$ & 138.1 & 138.15 & 2264.35 & 2264.42 & $(n-1) * 85.05+R M$ \\
\hline $\mathrm{P}(\mathrm{MOx})_{\mathrm{n}} \underset{\mathrm{OH}}{\mathrm{C}=\mathrm{C}}+\mathrm{H}^{+}(4)$ & $\mathrm{C}_{3} \mathrm{OH}_{5}$ & 57 & 57.1 & 2268.3 & 2268.40 & $\mathrm{n} * 85.05+\mathrm{RM}$ \\
\hline 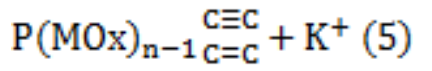 & $\mathrm{C}_{7} \mathrm{H}_{9} \mathrm{NOK}$ & 162.1 & 163.05 & 2288.35 & 2289.33 & $(n-1) * 85.05+R M$ \\
\hline $\mathrm{P}(\mathrm{MOx})_{\mathrm{n}-1} \underset{\mathrm{Oxa}}{\mathrm{H}}(6)$ & $\mathrm{C}_{4} \mathrm{H}_{8} \mathrm{NO}$ & 86 & 86 & 2297.3 & 2297.30 & $(n-1) * 85.05+R M$ \\
\hline
\end{tabular}

RM: residual mass.

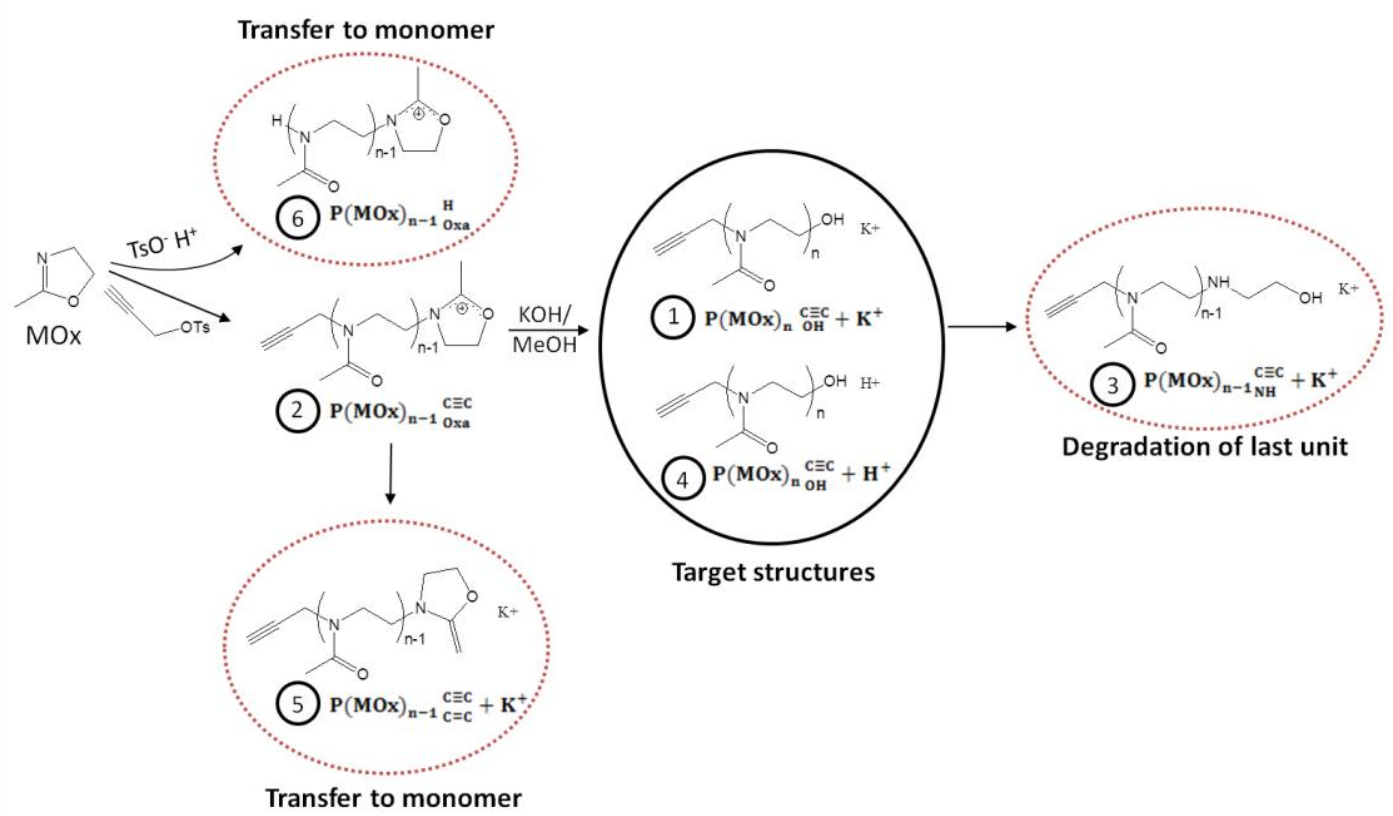

Scheme 2. Chemical structures of poly(2-methyl-2-oxazoline) chains found by MALDI-Tof analysis (polymerization and side reactions). 
The MALDI-Tof spectrum of $\omega-\mathrm{N}_{3}-\mathrm{P}(\mathrm{t}-\mathrm{BA})$ was also deeply investigated. It was composed of three different distributions as illustrated in Figure 2 and Table 2. The main population (structure 1) was attributed to the targeted structure (structure 1: $\mathrm{P}(t-\mathrm{BA})_{\mathrm{n}}{ }_{\mathrm{N} 3}^{\text {ester }}$ ), corresponding to a poly(tert-butyl acrylate) with an ethyl propionate head group coming from the initiator and an azide end group. Two other minor distributions were detected. The first one was attributed to a $P(t-B A)$ with an azide end group and an acrylic acid head group (structure 2: $\mathrm{P}(t-\mathrm{BA})_{\mathrm{n}_{\mathrm{N} 3}}^{\text {acid }}$ ) whereas the other one corresponded to the structure $3\left(\mathrm{P}(t-\mathrm{BA})_{\mathrm{n}_{\mathrm{OH}}}{ }^{\text {ester }}\right)$, in which the bromide atom was substituted by an hydroxyl group. From MALDI-Tof spectroscopy, we can conclude that functionalization of both PMOx and PtBA homopolymers by propargylic and azido groups, respectively, is almost quantitative.

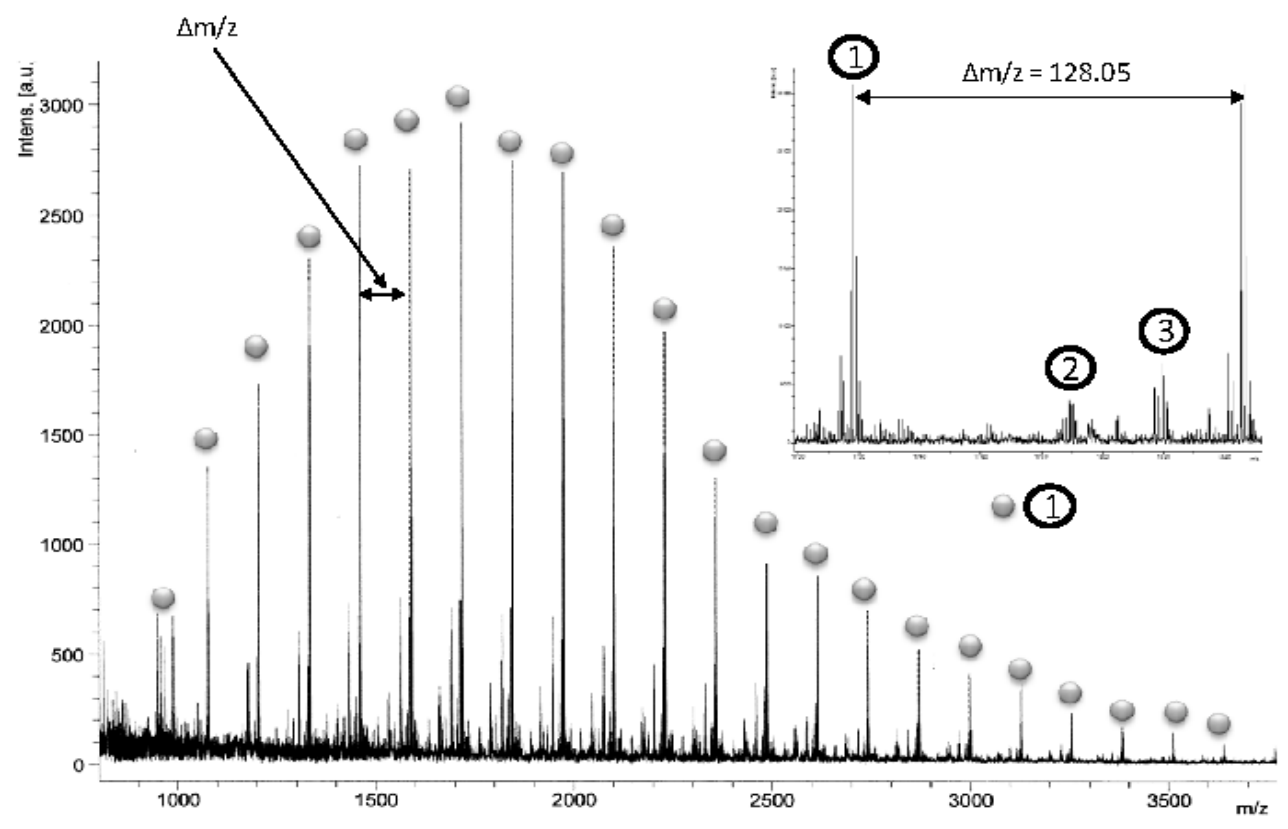

Figure 2. MALDI-Tof spectrum of the $\omega$ - $\mathrm{N}_{3}$-poly(tert-butyl acrylate) $\left(\mathrm{M}_{n, \text { th }}=2200 \mathrm{~g} \cdot \mathrm{mol}^{-1}\right)(2,3-$ dihydrobenzoic acid matrix with $\mathrm{Nal}$ ). 
Table 2. Analytical data derived from MALDI-Tof spectroscopy for the characterization of $\omega-\mathrm{N}_{3}$-poly(tertbutyl acrylate) $\left(\mathrm{M}_{\mathrm{n}, \mathrm{th}}=2200 \mathrm{~g} \cdot \mathrm{mol}^{-1}\right)$.

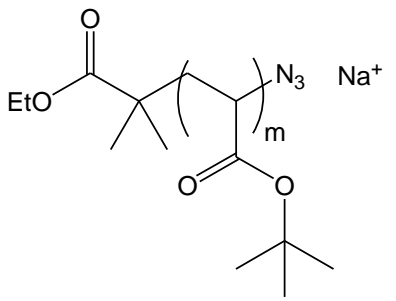

(1)

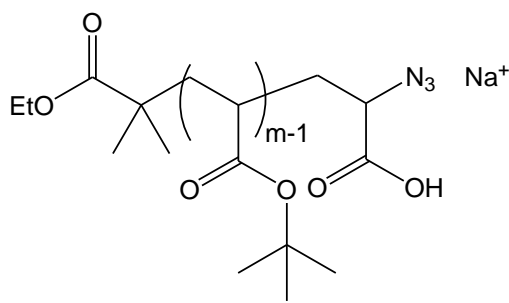

(2)

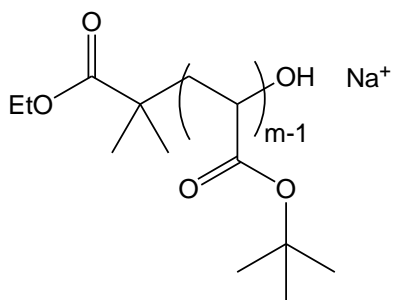

(3)

\begin{tabular}{|c|c|c|c|c|c|c|}
\hline Assignment & $\mathbf{R M}_{\text {formula }}$ & $\mathbf{R M}_{\mathrm{cal}}$ & $\mathbf{R} \mathbf{M}_{\text {exp }}$ & $M_{p, \text { cal }}$ & $M_{p, \exp }$ & Calculation \\
\hline $\mathrm{P}(t \mathrm{BA})_{\mathrm{m}} \underset{\mathrm{N}_{\mathrm{g}}}{\operatorname{Ini}}+\mathrm{Na}^{+}(1)$ & $\mathrm{C}_{6} \mathrm{O}_{2} \mathrm{~N}_{3} \mathrm{H}_{11} \mathrm{Na}$ & 180.19 & 180.45 & 1716.79 & 1717.05 & $m * 128.05+R M$ \\
\hline $\mathrm{P}(t \mathrm{BA})_{\mathrm{m}-1} \operatorname{Ini}_{\text {acid }+\mathrm{N}_{\mathrm{g}}}+\mathrm{Na}^{+}(2)$ & $\mathrm{C}_{9} \mathrm{O}_{4} \mathrm{~N}_{3} \mathrm{H}_{15} \mathrm{Na}$ & 252.26 & 251.48 & 1788.86 & 1788.08 & $(m-1) * 128.05+R M$ \\
\hline $\mathrm{P}(t \mathrm{BA})_{\mathrm{m} \mathrm{OH}} \underset{\mathrm{Oni}}{\mathrm{Ini}}+\mathrm{Na}^{+}(3)$ & $\mathrm{C}_{6} \mathrm{O}_{3} \mathrm{H}_{12} \mathrm{Na}$ & 155.17 & 153.48 & 1819.82 & 1818.13 & $m^{*} 128.05+R M$ \\
\hline
\end{tabular}

RM: residual mass.

\section{Polymer-polymer coupling by CuAAC chemistry}

The polymer-polymer coupling between $\alpha$-alkyne-P(MOx) and $\omega-\mathrm{N}_{3}-\mathrm{P}(\mathrm{t}-\mathrm{BA})$ homopolymers was carried out using the copper-catalyzed azide-alkyne Huisgen 1,3-dipolar cycloaddition (CuAAC) as displayed in Scheme 1. In the typical coupling protocol, both blocks were dissolved in DMF in the presence of copper (I) bromide $(\mathrm{Cu}(\mathrm{l}) \mathrm{Br})$ and PMDETA at $50{ }^{\circ} \mathrm{C}$ under nitrogen during one week. The difficulty of this approach was to couple macromolecular segments with antagonist properties, which was not favored. To explore potential scope of the coupling reaction and to obtain amphiphilic copolymers with various lengths of hydrophilic and hydrophobic blocks, $\mathrm{P}(\mathrm{MOx})$ blocks of 1000 and $2200 \mathrm{~g}^{\mathrm{mol}} \mathrm{m}^{-1}$ and hydrophobic $\mathrm{P}(\mathrm{t}-\mathrm{BA})$ blocks of 2500,3900 and $14500 \mathrm{~g} \cdot \mathrm{mol}^{-1}$ were combined. Coupling reaction was successful when low molar mass $\mathrm{P}(\mathrm{MOx})$ reacted with low molecular weight $\mathrm{P}(\mathrm{t}-\mathrm{BA})$ (DPn equal to 19 and 30) (Table 3). On the other hand, CuAAC did not occur for higher P(t-BA) molecular weight (DPn equal to 113) as no shift of the size exclusion chromatography trace was observed. This result was explained by the high hydrophilic character of $\mathrm{P}(\mathrm{MOx})$ which was unfavorable for coupling with a hydrophobic block. 
Table 3. Characterization data for $\mathrm{P}(\mathrm{MOx})_{\mathrm{n}}-b-\mathrm{P}(\mathrm{t}-\mathrm{BA})_{\mathrm{m}}$ amphiphilic diblock copolymers.

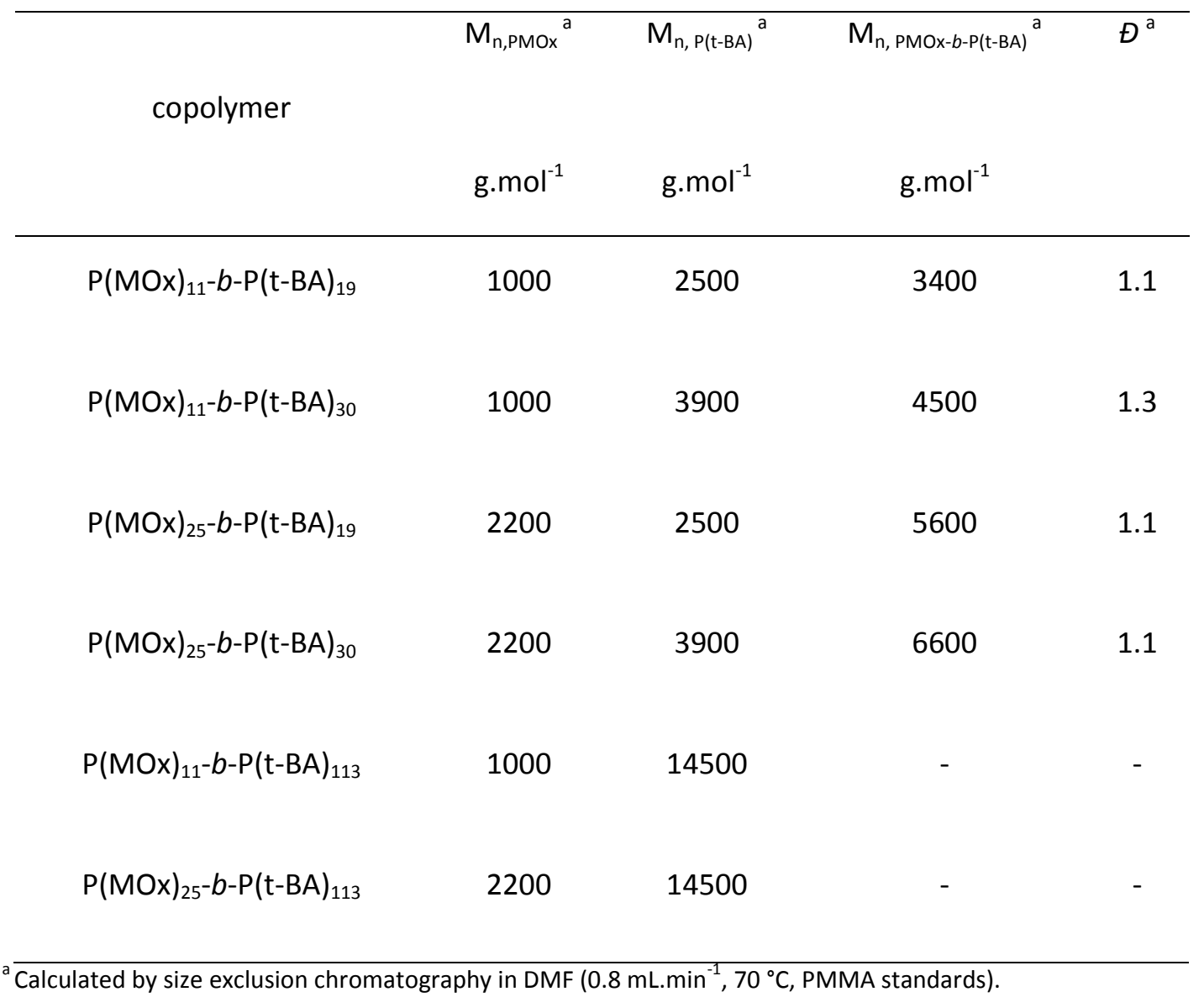

${ }^{1} \mathrm{H} N M R$ in deuterated chloroform showed the signals corresponding to the proton of the triazole ring and to the proton of the tert-butyl acrylate moiety linked to the nitrogen atom of the triazole at 8 and $4.2 \mathrm{ppm}$, respectively (Figure 3). We also noticed the presence of signals corresponding to both $\mathrm{P}(\mathrm{MOx})$ and $\mathrm{P}(\mathrm{t}-\mathrm{BA})$ moieties, indicating that the coupling was probably effective. To confirm that point, amphiphilic copolymers synthesized were also characterized by 2D diffusion-ordered NMR spectroscopy (DOSY) analysis which produced two-dimensional correlation maps showing chemical shifts and diffusion coefficient on the horizontal and vertical axes, respectively. ${ }^{43}$ This powerful technique allowed discriminating macromolecules by its diffusion coefficient e.g. precursor polymers and resulting copolymers. ${ }^{44}$ The 2D DOSY NMR spectra of the $\mathrm{P}(\mathrm{MOx})_{25}, \mathrm{P}(\mathrm{t}-\mathrm{BA})_{30}$ homopolymers and the resulting $\mathrm{P}(\mathrm{MOx})_{25}-b-\mathrm{P}(\mathrm{t}-\mathrm{BA})_{30}$ were achieved in DMF- $d_{7}$ (Figure 4). The diffusion coefficient values of $\alpha$-alkyne$\mathrm{P}(\mathrm{MOx})$ and of the $\omega-\mathrm{N}_{3}-\mathrm{P}(\mathrm{t}-\mathrm{BA})$ were measured (blue and red dotted line, respectively) and proved to be different (-9.61 and $-9.4 \mathrm{~m}^{2} . \mathrm{s}^{-1}$, respectively). On the other hand, $\mathrm{P}(\mathrm{MOx})$ and $\mathrm{P}(\mathrm{t}-\mathrm{BA})$ signals had the same diffusion coefficient value $\left(-9.9 \mathrm{~m}^{2} . \mathrm{s}^{-1}\right)$ for the $\mathrm{P}(\mathrm{MOx})_{25}-b-\mathrm{P}(\mathrm{t}-\mathrm{BA})_{30}$ amphiphilic copolymer, thereby demonstrating the effective coupling between the $\mathrm{P}(\mathrm{MOx})$ and $\mathrm{P}(\mathrm{t}-\mathrm{BA})$ blocks. There was also no signal of uncoupled homopolymers which confirmed that copolymer was pure. 


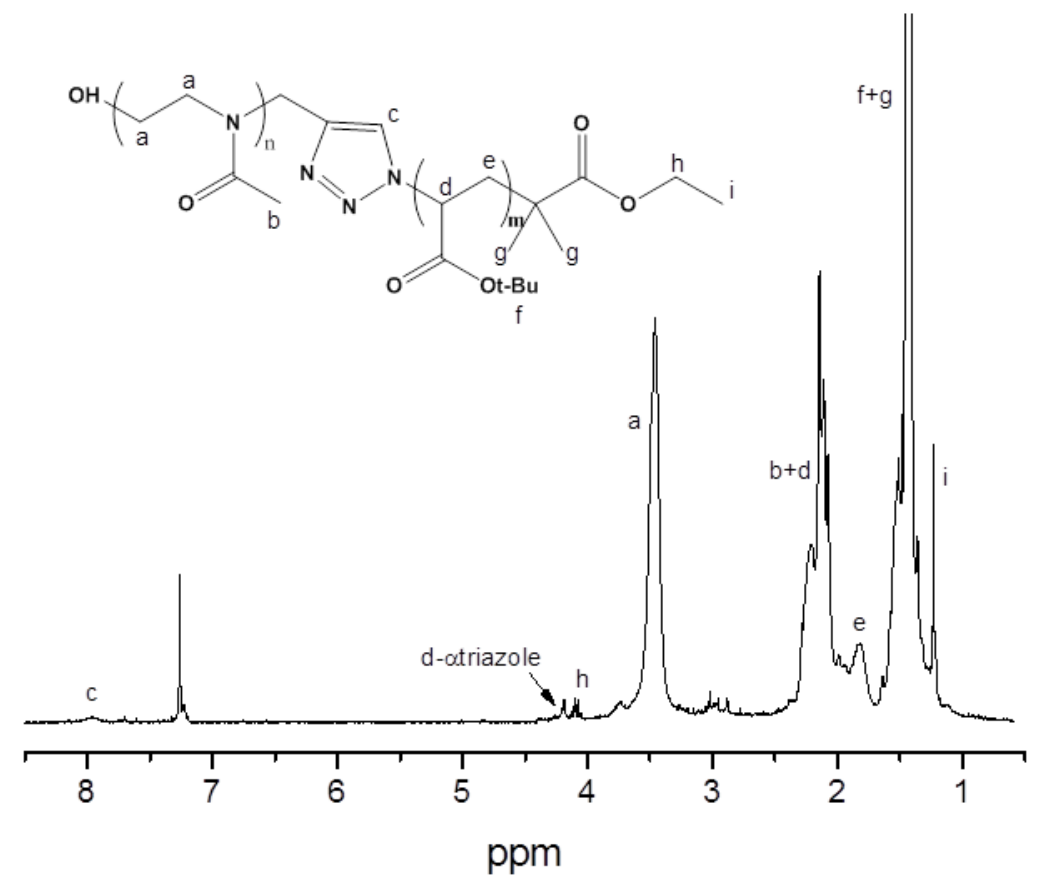

Figure 3. ${ }^{1} \mathrm{H} N M R$ spectrum of $\mathrm{P}(\mathrm{MOx})_{25}-b-\mathrm{P}(\mathrm{t}-\mathrm{BA})_{19}$ in deuterated chloroform.

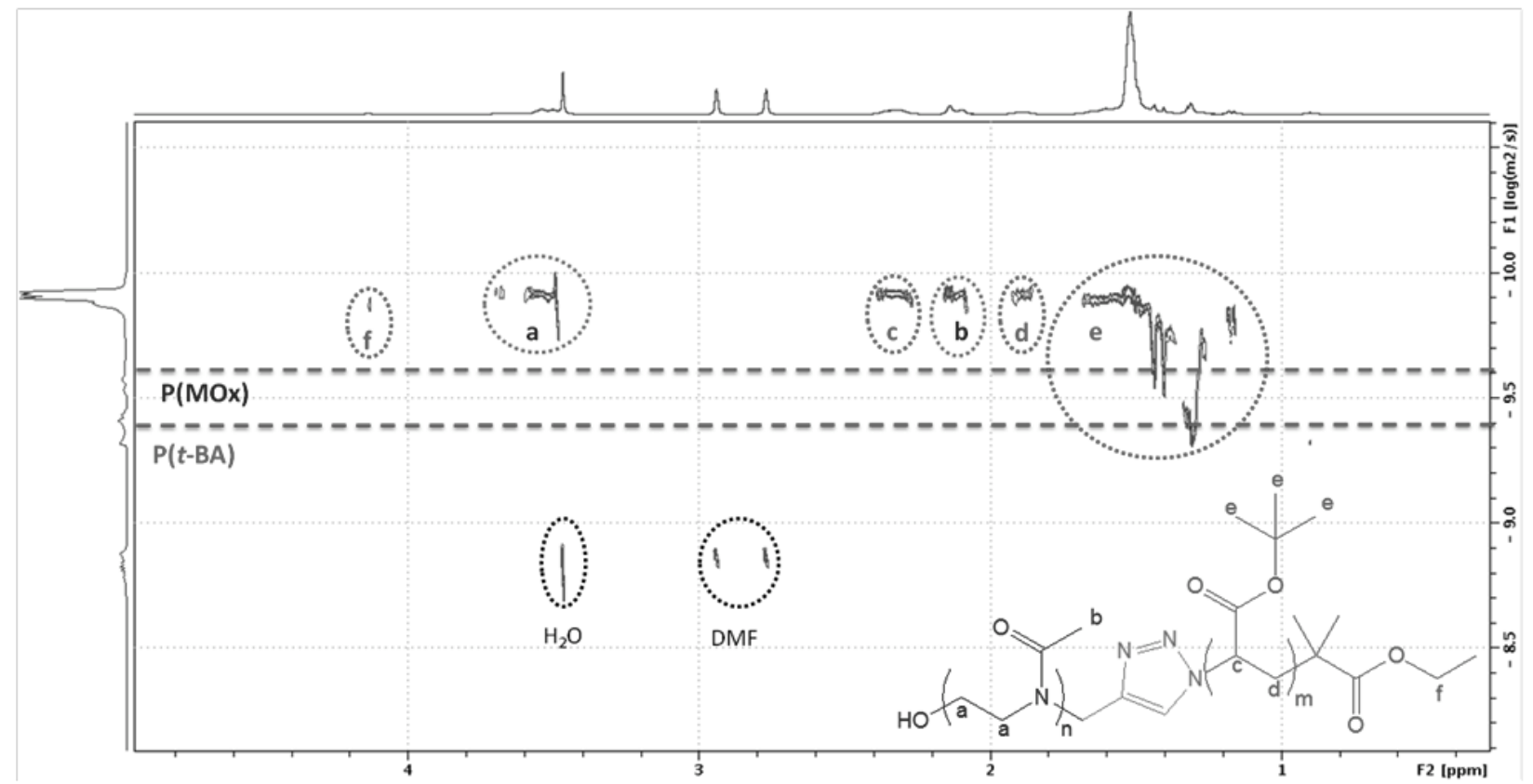

Figure 4. 2D DOSY NMR in DMF- $d_{7}$ of $\alpha$-alkyne-P(MOx) $)_{25}$ (blue dotted line), $\omega-\mathrm{N}_{3}-\mathrm{P}(\mathrm{t}-\mathrm{BA})_{30}$ (red dotted line), and $\mathrm{P}(\mathrm{MOx})_{25}-b-\mathrm{P}(\mathrm{t}-\mathrm{BA})_{30}$ copolymer. 
Additional proof for the obtaining of $\mathrm{P}(\mathrm{MOx})_{\mathrm{n}}-b-\mathrm{P}(\mathrm{t}-\mathrm{BA})_{\mathrm{m}}$ block copolymers was given by the normalized size exclusion chromatography $(\mathrm{SEC})$ traces of the individual precursor polymers as well as the resulting $\mathrm{P}(\mathrm{MOx})_{25}-b-\mathrm{P}(\mathrm{t}-\mathrm{BA})_{30}$ block copolymer (Figure 5). The same graphs were realized for all $\mathrm{P}(\mathrm{MOx})_{\mathrm{n}}-b-\mathrm{P}(\mathrm{t}-$ $B A)_{m}$ copolymers (supporting information, Figures S5-S7). The shift of the SEC trace for the block copolymers to a lower elution time in comparison with the initial homopolymers clearly indicated the effectiveness of the coupling process via CuAAC in the case of low $\mathrm{P}(\mathrm{MOx})$ and $\mathrm{P}(\mathrm{t}-\mathrm{BA})$ molecular weights, and copolymers were obtained with low dispersities ( $\theta$ between 1.1-1.3) (Table 3). In conclusion, from all the results obtained, we concluded that pure $\mathrm{P}(\mathrm{MOx})_{\mathrm{n}}-b-\mathrm{P}(\mathrm{t}-\mathrm{BA})_{\mathrm{m}}$ amphiphilic block copolymers were isolated. As a consequence, their self-assembly in water was studied.

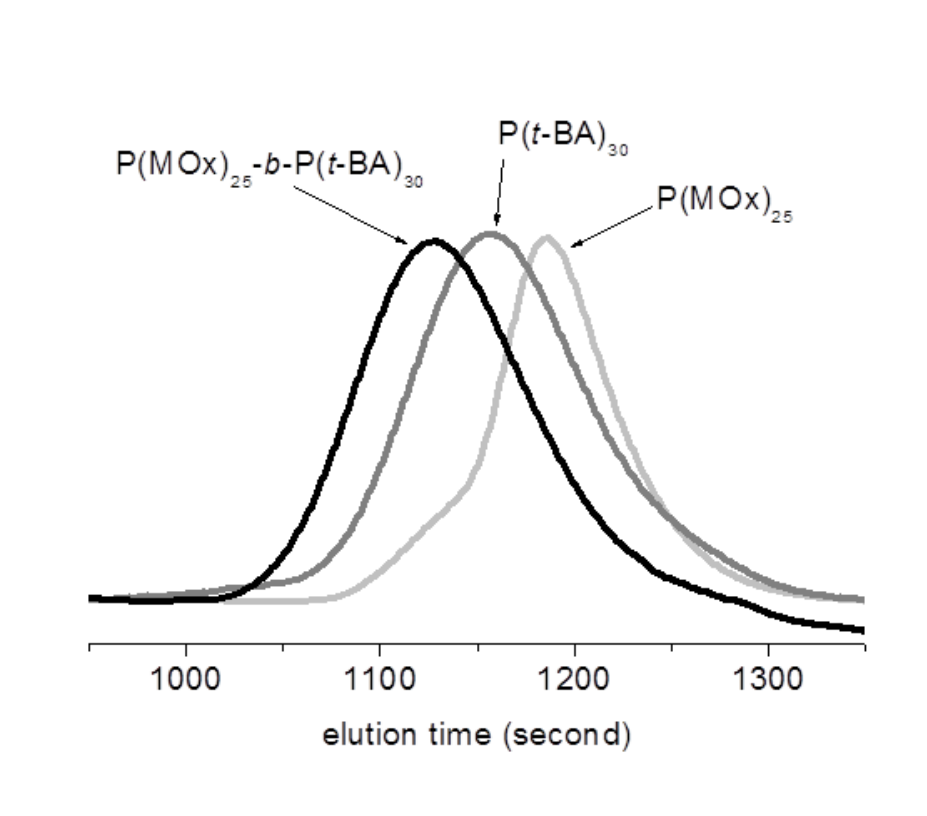

Figure 5. SEC profiles of $\alpha$-alkyne-P(MOx) ${ }_{11}$ (blue line), $\omega-\mathrm{N}_{3}-\mathrm{P}(\mathrm{t}-\mathrm{BA})_{19}$ (red line) and resulting $\mathrm{P}(\mathrm{MOx})_{11^{-}}$ $b$-P(t-BA $)_{19}$ diblock copolymer (green line) (eluent: DMF, $0.8 \mathrm{~mL} \cdot \mathrm{min}^{-1}, 70{ }^{\circ} \mathrm{C}$, standards: PMMA).

\section{Self-assembling of $P(M O x)_{n}-b-P(t-B A)_{m}$ amphiphilic copolymers}

The ability of block copolymers to self-assemble in selective solvents allowed various well-defined nanostructures with tunable sizes and morphologies such as micelles, for instance. Solutions of $P(M O x)_{n^{-}}$ $b-\mathrm{P}(\mathrm{t}-\mathrm{BA})_{\mathrm{m}}\left(0.3 \mathrm{mg} \cdot \mathrm{mL}^{-1}\right)$ were prepared in DMF which was a good solvent for both $\mathrm{P}(\mathrm{MOx})$ and $\mathrm{P}(\mathrm{t}-\mathrm{BA})$ blocks, dialyzed against MilliQ water, and finally filtered through a membrane with a nominal pore size of $0.45 \mu \mathrm{m} .{ }^{1,45}$ Thus, in water, we expected copolymers to form micelles composed of $\mathrm{P}(\mathrm{t}-\mathrm{BA})$ micellar core surrounded by a $\mathrm{P}(\mathrm{MOx})$ corona.

The morphology of polymer aggregates was first studied by atomic force microscopy (AFM) and transmission electron microscopy (TEM). All samples were characterized in bulk. $\mathrm{P}(\mathrm{MOx})_{11}-b-\mathrm{P}(\mathrm{t}-\mathrm{BA})_{30}$ was chosen to illustrate the self-assembling of these copolymers as shown in Figure 6 (see also 
supporting information, Figure S8). AFM measurements were carried out in air using silicon wafers treated with RCA in the tapping mode whereas TEM micrographs were obtained by casting of a dilute micellar solution on a carbon-coated copper grid. The TEM and AFM pictures were in agreement with the formation of spherical micelles. Radii determined by TEM (Table 4) were relatively high due to the tip convolution effects and/or the flattening of the object on the surface. ${ }^{46-47}$

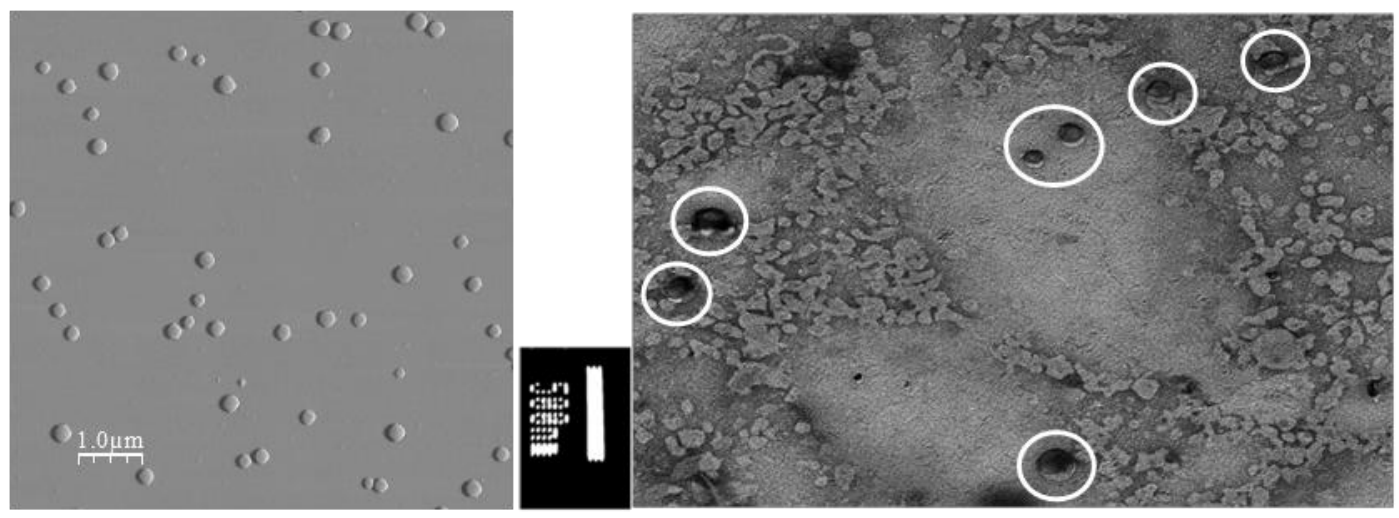

Figure 6. AFM (left) and TEM (right) images of micelles $\left(\mathrm{P}(\mathrm{MOx})_{11}-b-\mathrm{P}(\mathrm{t}-\mathrm{BA})_{30}\right)$.

Table 4. Radius and height of the micelles determined by Atomic Force Microscopy (AFM).

\begin{tabular}{ccc}
\hline Copolymer & $\mathrm{R}(\mathrm{nm})$ & $\mathrm{H}(\mathrm{nm})$ \\
\hline $\mathrm{P}(\mathrm{MOx})_{11}-b-\mathrm{P}(t-\mathrm{BA})_{19}$ & 50 & 20 \\
$\mathrm{P}(\mathrm{MOx})_{11}-b-\mathrm{P}(t-\mathrm{BA})_{30}$ & 120 & 75 \\
$\mathrm{P}(\mathrm{MOx})_{25}-b-\mathrm{P}(t-\mathrm{BA})_{19}$ & 85 & 35 \\
$\mathrm{P}(\mathrm{MOx})_{25}-b-\mathrm{P}(t-\mathrm{BA})_{30}$ & 150 & 60 \\
\hline
\end{tabular}

The copolymer mixtures were then analyzed by both fluorescence spectroscopy and static light scattering (SLS) in order to determine the critical micellar concentration (CMC) of $\mathrm{P}(\mathrm{MOx})_{\mathrm{n}}-b-\mathrm{P}(\mathrm{t}-\mathrm{BA})_{\mathrm{m}}$ nanoparticles. In the first technique, pyrene was chosen as the fluorescent probe since it preferentially partitions into hydrophobic microenvironments with a concurrent change in the fluorescence intensities. ${ }^{48}$ From the plot of fluorescence intensity versus copolymer concentration (Figure $7 a$ and supporting information, Figure S9), an abrupt decrease in $I_{1} / l_{3}$ value was detected during increasing copolymer concentrations, indicating the formation of micelles and the transfer of pyrene into the hydrophobic core of the micelles. The critical micellar concentration (CMC) was found around $35 \mathrm{mg} \cdot \mathrm{L}^{-1}$, except for the $\mathrm{P}(\mathrm{MOx})_{25}-b-\mathrm{P}(\mathrm{t}-\mathrm{BA})_{19}$ which showed a $\mathrm{CMC}$ at $11 \mathrm{mg} \cdot \mathrm{L}^{-1}$ (Table 5). This value was a little bit 
surprising and from all the results we assumed that the CMC depended on the hydrophilic block length only when hydrophobic block was short.

Table 5. Characterization of $\mathrm{P}(\mathrm{MOx})_{\mathrm{n}}-b-\mathrm{P}(\mathrm{t}-\mathrm{BA})_{\mathrm{m}}$ in water by fluorescence spectroscopy and scattering light experiments.

\begin{tabular}{ccccc}
\hline $\begin{array}{c}\mathrm{CMC}_{\text {fluo }} \\
\left(\mathrm{mg} \cdot \mathrm{L}^{-1}\right)\end{array}$ & $\begin{array}{c}\mathrm{CMC}_{\mathrm{SLS}} \\
\left(\mathrm{mg} \cdot \mathrm{L}^{-1}\right)\end{array}$ & $\begin{array}{c}\mathrm{R}_{\mathrm{H}}{ }^{\mathrm{a}} \\
(\mathrm{nm})\end{array}$ & Dispersity $^{\mathrm{a}}$ \\
\hline $\mathrm{P}(\mathrm{MOx})_{11}-b-\mathrm{P}(\mathrm{t}-\mathrm{BA})_{19}$ & 35 & 36 & 40 & 0.21 \\
$\mathrm{P}(\mathrm{MOx})_{11}-b-\mathrm{P}(\mathrm{t}-\mathrm{BA})_{30}$ & 34 & 38 & 45 & 0.21 \\
$\mathrm{P}(\mathrm{MOx})_{25}-b-\mathrm{P}(\mathrm{t}-\mathrm{BA})_{19}$ & 11 & 19 & 55 & 0.11 \\
$\mathrm{P}(\mathrm{MOx})_{25}-b-\mathrm{P}(\mathrm{t}-\mathrm{BA})_{30}$ & 36 & 45 & 60 & 0.18 \\
\hline determined by Dynamic Light Scattering (DLS) from CONTIN method.
\end{tabular}

The CMC was also determined by static light scattering (SLS), tracking the intensity as a function of concentration (Figure $7 \mathrm{~b}$ and supporting information Figures 59-11). For lower concentration in copolymer, a very weak scattered intensity corresponding to unimers was detected whereas the dramatically increase of intensity indicated the formation of micellar structures. The CMC determined by fluorescence spectroscopy were closed from the literature ${ }^{49}$ and from those determined by SLS. Once again, the lowest $C M C$ value was obtained for the $\mathrm{P}(\mathrm{MOx})_{25}-b-\mathrm{P}(\mathrm{t}-\mathrm{BA})_{19}$ amphiphilic copolymer, confirming the fluorescence measurements.
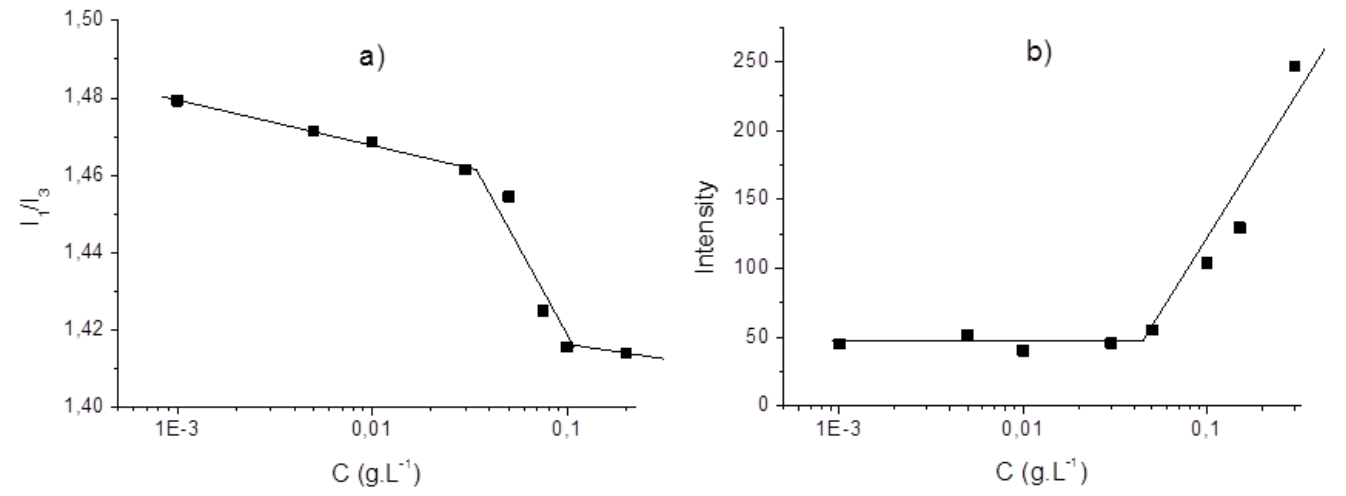

Figure 7. $\mathrm{CMC}$ a) by fluorescence spectroscopy ( $\left[\mathrm{P}(\mathrm{MOx})_{11}-b-\mathrm{P}(\mathrm{t}-\mathrm{BA})_{30}\right]$ varied from $1 \times 10^{-3}$ to $0.2 \mathrm{mg} \cdot \mathrm{mL}^{-1}$; $[$ pyrene $\left.\left.]=9 \times 10^{-7} \mathrm{M}\right) ; \mathrm{b}\right)$ by static light scattering measurements $\left(\left[\mathrm{P}(\mathrm{MOx})_{11^{-}}-\mathrm{b}-\mathrm{P}(\mathrm{t}-\mathrm{BA})_{30}\right]\right.$ varied from $1 \times 10^{-}$ ${ }^{3}$ to $0.2 \mathrm{mg} \cdot \mathrm{mL}^{-1}$ ). 
Dynamic light scattering (DLS) experiments were performed on copolymer dissolved in water (C = 50 $\mathrm{mg} \cdot \mathrm{mL}^{-1}$ ) to get more details on the size distribution and to better determine the hydrodynamic radius $\left(R_{H}\right)$ of the micelles (Figure 8 and supporting information, Figure S11). From the Stokes-Einstein equation, $R_{H}$ was calculated from the DLS correlation function using CONTIN algorithm. For all $\mathrm{P}(\mathrm{MOx})_{\mathrm{n}}{ }^{-}$ $b$ - $\mathrm{P}(\mathrm{t}-\mathrm{BA})_{\mathrm{m}}$ copolymers, the results confirmed the obtaining of monodisperse micelles, showing a polydispersity index around $0.11-0.21$ (Table 5). The $R_{H}$ of the micelles ranged from 40 to $60 \mathrm{~nm}$ for $\mathrm{P}(\mathrm{MOx})_{11}-b-\mathrm{P}(\mathrm{t}-\mathrm{BA})_{\mathrm{m}}$ and $\mathrm{P}(\mathrm{MOx})_{25}-b-\mathrm{P}(\mathrm{t}-\mathrm{BA})_{\mathrm{m}}$, respectively. We concluded that the hydrodynamic radius was dependant of the hydrophilic poly(oxazoline) block.

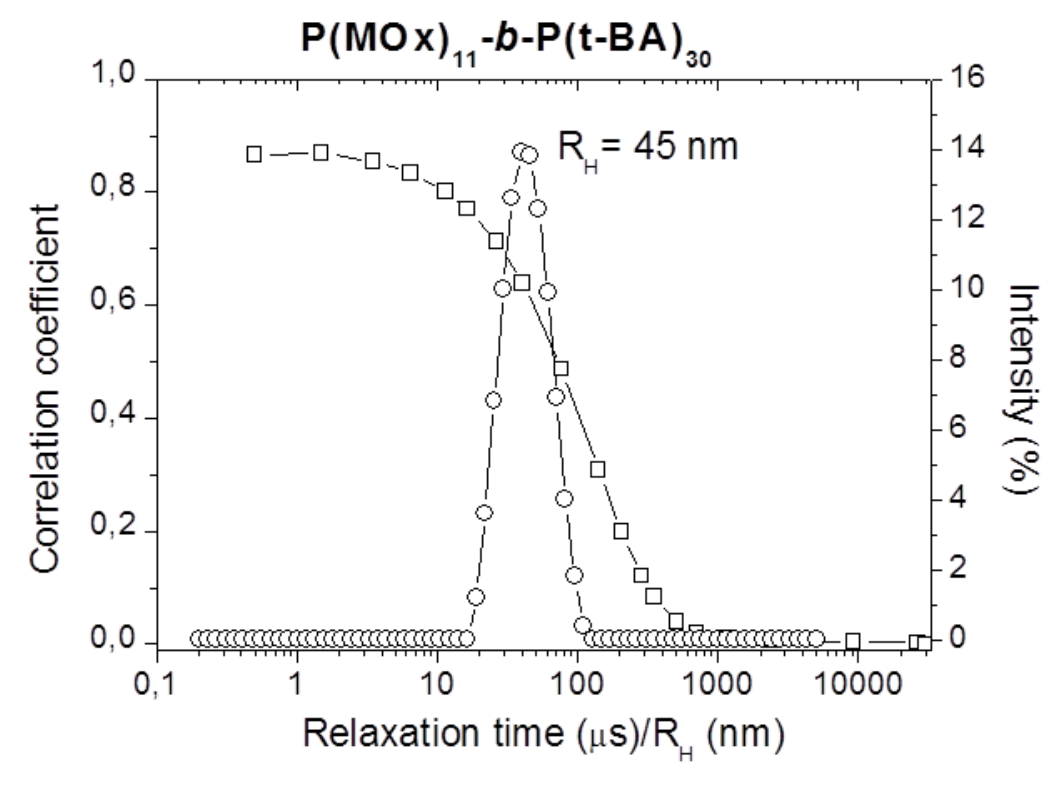

Figure 8. Autocorrelation function measured by DLS at scattering angle equal to $\theta=173^{\circ}$, at $25{ }^{\circ} \mathrm{C}$ and distribution of the hydrodynamic radius calculated by CONTIN algorithm for $50 \mathrm{mg} \cdot \mathrm{L}^{-1}$ for $\mathrm{P}(\mathrm{MOx})_{11^{-}} b$ $P(t-B A)_{30}$.

\section{CONCLUSIONS}

In conclusion, this work reported the synthesis of $\mathrm{P}(\mathrm{MOx})_{\mathrm{n}}-b-\mathrm{P}(\mathrm{t}-\mathrm{BA})_{\mathrm{m}}$ amphiphilic diblock copolymers by copper catalyzed azide-alkyne cycloaddition reaction. Such kind of synthesis was to date only rarely reported in the literature due to the antagonist properties of the combined homopolymers. $\alpha$-Alkynepolyoxazoline and $\omega-\mathrm{N}_{3}-\mathrm{P}(\mathrm{t}-\mathrm{BA})$ were first prepared and characterized by MALDI-Tof which proved the efficiency of CROP and ATRP to functionalize the end groups of $P(t-B A)$ and $P(M O x)$ by azide and alkyne end groups, respectively. Then, coupling of homopolymers was achieved varying molecular weights of both blocks and proved to be efficient for relatively low molecular weight derivatives. Resulting 
copolymers were successfully characterized by DOSY NMR and SEC, showing the interest of Huisgen's cycloaddition in polymer field. Finally, self-organization of $P(M O x)_{n}-b-P(t-B A)_{m}$ copolymers in water was studied. As polymer-polymer coupling was successful, allowing the obtaining of pure amphiphilic copolymers, we managed to form very well-defined micelles in water, which were fully characterize by fluorescence spectroscopy, SLS, DLS, and microscopy.

ACKNOWLEDGEMENTS. The authors would like to thanks the French Ministry of Education and Research for a grant (B.G.), and Dr. Romain Parret and Prof. Jean-Marie Devoisselle for technical assistance in AFM and fluorescence spectroscopy, respectively. 


\section{REFERENCES AND NOTES}

(1) Gohy, J.-F. In Block Copolymers II; Abetz, V., Ed.; Springer Berlin / Heidelberg, 2005; Vol. 190.

(2) Guillerm, B.; Darcos, V.; Lapinte, V.; Monge, S.; Coudane, J.; Robin, J.-J. Chemical Communications 2012, 48, 2879-2881.

(3) Wang, D.; Su, Y.; Jin, C.; Zhu, B.; Pang, Y.; Zhu, L.; Liu, J.; Tu, C.; Yan, D.; Zhu, X. Biomacromolecules 2011, 12, 1370-1379.

(4) Quémener, D.; Bonniol, G.; Phan, T. N. T.; Gigmes, D.; Bertin, D.; Deratani, A. Macromolecules 2010, 43, 5060-5065.

(5) Tasdelen, M. A.; Kahveci, M. U.; Yagci, Y. Progress in Polymer Science 2011, 36, 455-567.

(6) Rayeroux, D.; Lapinte, V.; Lacroix-Desmazes, P. Journal of Polymer Science Part A: Polymer Chemistry 2012, DOI: 10.1002/pola.26291.

(7) Becer, C. R.; Paulus, R. M.; Hoeppener, S.; Hoogenboom, R.; Fustin, C.-A.; Gohy, J.-F.; Schubert, U. S. Macromolecules 2008, 41, 5210-5215.

(8) Krieg, A.; Weber, C.; Hoogenboom, R.; Becer, C. R.; Schubert, U. S. Acs Macro Letters 2012, 1, 776-779.

(9) Lahann, J. Click Chemistry for Biotechnology and Materials Science; John Wiley and Sons, Ldt: New Delhi, 2009.

(10) Fournier, D.; Hoogenboom, R.; Schubert, U. S. Chemical Society Reviews 2007, 36, 1369-1380.

(11) Opsteen, J. A.; Brinkhuis, R. P.; Teeuwen, R. L. M.; Lowik, D.; van Hest, J. C. M. Chemical Communications 2007, 3136-3138.

(12) Hoyle, C. E.; Bowman, C. N. Angewandte Chemie International Edition 2010, 49, 1540-1573.

(13) Li, G. Z.; Randev, R. K.; Soeriyadi, A. H.; Rees, G.; Boyer, C.; Tong, Z.; Davis, T. P.; Becer, C. R.; Haddleton, D. M. Polymer Chemistry 2010, 1, 1196-1204.

(14) Hansell, C. F.; Espeel, P.; Stamenovic, M. M.; Barker, I. A.; Dove, A. P.; Du Prez, F. E.; O'Reilly, R. K. Journal of the American Chemical Society 2011, 133, 13828-13831.

(15) Kyeremateng, S. O.; Busse, K.; Kohlbrecher, J.; Kressler, J. Macromolecules 2011, 44, 583-593.

(16) Lonsdale, D. E.; Monteiro, M. J. Journal of Polymer Science Part A: Polymer Chemistry 2011, 49, 4603-4612.

(17) Opsteen, J. A.; van Hest, J. C. M. Chemical Communications 2005, 57-59.

(18) Babinot, J.; Renard, E.; Langlois, V. Macromolecular Chemistry and Physics 2011, 212, 278-285.

(19) Tao, X. D.; Gao, Z. G.; Satoh, T.; Cui, Y. A.; Kakuchi, T.; Duan, Q. Polymer Chemistry 2011, 2, 20682073.

(20) Volet, G.; Lav, T.-X.; Babinot, J.; Amiel, C. Macromolecular Chemistry and Physics 2011, 212, 118124.

(21) Cortez, M.; Grayson, S. M. PMSE Preprints 2008, 98, 438-439.

(22) Lemechko, P.; Renard, E.; Volet, G.; Simon Colin, C.; Guezennec, J.; Langlois, V. Reactive and Functional Polymers 2012, 72, 160-167.

(23) Isaacman, M. J.; Barron, K. A.; Theogarajan, L. S. Journal of Polymer Science Part a-Polymer Chemistry 2012, 50, 2319-2329.

(24) Viegas, T. X.; Bentley, M. D.; Harris, J. M.; Fang, Z.; Yoon, K.; Dizman, B.; Weimer, R.; Mero, A.; Pasut, G.; Veronese, F. M. Bioconjugate Chemistry 2011, 22, 976-986.

(25) Zalipsky, S.; Hansen, C. B.; Oaks, J. M.; Allen, T. M. Journal of Pharmaceutical Sciences 1996, 85, 133-137.

(26) Adams, N.; Schubert, U. S. Advanced Drug Delivery Reviews 2007, 59, 1504-1520.

(27) Kempe, K.; Vollrath, A.; Schaefer, H. W.; Poehlmann, T. G.; Biskup, C.; Hoogenboom, R.; Hornig, S.; Schubert, U. S. Macromol. Rapid Commun. 2010, 31, 1869-1873. 
(28) Goddard, P.; Hutchinson, L. E.; Brown, J.; Brookman, L. J. Journal of Controlled Release 1989, 10, 5-16.

(29) Gaertner, F. C.; Luxenhofer, R.; Blechert, B.; Jordan, R.; Essler, M. Journal of Controlled Release 2007, 119, 291-300.

(30) Woodle, M. C.; Engbers, C. M.; Zalipsky, S. Bioconjugate Chemistry 1994, 5, 493-496.

(31) Varshney, S. K.; Kesani, P.; Agarwal, N.; Zhang, J. X.; Rafailovich, M. Macromolecules 1998, 32, 235-237.

(32) Becker, M. L.; Liu, J.; Wooley, K. L. Biomacromolecules 2004, 6, 220-228.

(33) Perrin, D. Purification of Laboratory Chemicals; Pergamon Press: New-York, 1980.

(34) Keller, R. N.; Wycoff, H. D. Inorganic Syntheses 1946, 2, 1-4.

(35) Horcas, I.; Fernandez, R.; Gomez-Rodriguez, J. M.; Colchero, J.; Gomez-Herrero, J.; Baro, A. M. Review of Scientific Instruments 2007, 78.

(36) Fijten, M. W. M.; Haensch, C.; van Lankvelt, B. M.; Hoogenboom, R.; Schubert, U. S. Macromolecular Chemistry and Physics 2008, 209, 1887-1895.

(37) Zhang, X.; Giani, O.; Monge, S.; Robin, J.-J. European Polymer Journal 2008, 44, 3676-3687.

(38) Monge, S.; Giani, O.; Ruiz, E.; Cavalier, M.; Robin, J. J. Macromol. Rapid Commun. 2007, 28, 2272-2276.

(39) de Lambert, B.; Charreyre, M.-T.; Chaix, C.; Pichot, C. Polymer 2007, 48, 437-447.

(40) Baumgaertel, A.; Weber, C.; Knop, K.; Crecelius, A.; Schubert, U. S. Rapid Communications in Mass Spectrometry 2009, 23, 756-762.

(41) Guillerm, B.; Monge, S.; Lapinte, V.; Robin, J.-J. Macromolecules 2010, 43, 5964-5970.

(42) Park, J.-S.; Akiyama, Y.; Winnik, F. M.; Kataoka, K. Macromolecules 2004, 37, 6786-6792.

(43) Morris, K. F.; Johnson, C. S. Journal of the American Chemical Society 1992, 114, 3139-3141.

(44) Bakkour, Y.; Darcos, V.; Li, S.; Coudane, J. Polymer Chemistry 2012, 3, 2006-2010.

(45) Moughton, A. O.; O'Reilly, R. K. Journal of the American Chemical Society 2008, 130, 8714-8725.

(46) Mantzaridis, C.; Pispas, S. Journal of Polymer Science Part A: Polymer Chemistry 2011, 49, 30903098.

(47) Hoogenboom, R.; Wiesbrock, F.; Huang, H.; Leenen, M. A. M.; Thijs, H. M. L.; van Nispen, S. F. G. M.; van der Loop, M.; Fustin, C.-A.; Jonas, A. M.; Gohy, J.-F.; Schubert, U. S. Macromolecules 2006, 39, 4719-4725.

(48) Wilhelm, M.; Zhao, C. L.; Wang, Y.; Xu, R.; Winnik, M. A.; Mura, J. L.; Riess, G.; Croucher, M. D. Macromolecules 1991, 24, 1033-1040.

(49) Kim, C.; Lee, S. C.; Shin, J. H.; Yoon, J.-S.; Kwon, I. C.; Jeong, S. Y. Macromolecules 2000, 33, 74487452 . 